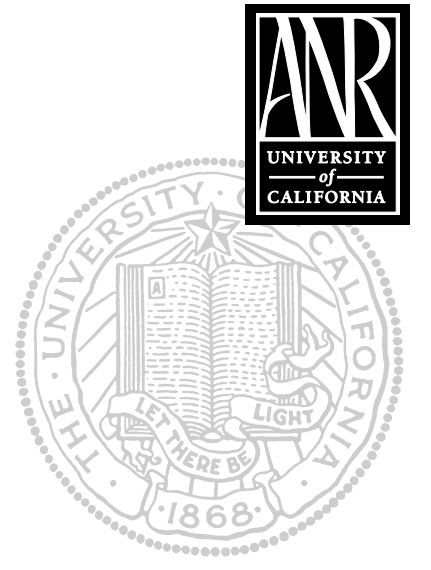

UNIVERSITY OF

CALIFORNIA

Division of Agriculture and Natural Resources

http://anrcatalog.ucdavis.edu

\section{PUBLICATION 8102}

\section{Key Points of Control and} Management of Microbial Food Safety: Information for Growers, Packers, and Handlers of Fresh-Consumed Horticultural
Products

TREVOR V. SUSLOW, UC Cooperative Extension Specialist, Department of Vegetable Crops, UC Davis.

Most horticultural products that are eaten fresh in the United States are wholesome and free of microorganisms that could result in illness under common and sensible handling and food preparation practices. Many of the diverse fruits, vegetables, edible flowers, sprouted seeds, and micro-greens have natural barriers that minimize the chance that any surface contamination could survive for long periods or be transferred to the internal edible portions, up to the point of harvest. These same barriers may also increase the effectiveness of washing and light to vigorous brushing (depending on the sensitivity of the item) for contamination removal. For some tolerant commodities, a combination of dry brushing, treatment with a volatile antimicrobial agent, and rapid drying is effective.

Contamination by microbial pathogens can only result, ultimately, from an external environmental source, and that can occur at any time from planting through food preparation. Nonetheless, as with all fruits and vegetables that are eaten uncooked, the best approach to maintaining the wholesome nature and safe consumption of edible horticultural products is to be aware of the potential risks and to systematically identify and establish management practices that minimize chances of external and internal contamination at every step from growing to selling. The industry must continue to take a proactive role in delivering this same message to the public in order to encourage safe food handling and preparation.

\section{BACKGROUND}

Whether they are produced domestically or imported, four key events have brought focus and concern for the microbial food safety of fresh fruits, vegetables, nuts, and other edible horticultural foods:

1. Recent and recurring disease outbreaks linked to the consumption of imported and domestic foods

2. Positive detection and recovery of human pathogens from random samples of both imported and domestic produce

3. Recent reports from several researchers indicating how difficult it is to clean and disinfect produce surfaces

4. Recent reports from several researchers documenting the potential for pathogens to move inside of produce during postharvest handling 
Based on the overall level of fresh produce consumption in the United States, the likelihood that a person will develop an illness that can be traced definitively to the contamination of fresh foods prior to food preparation is very low. It is equally clear, however, that disease outbreaks linked to fresh produce from various production areas have occurred and that those outbreaks have affected large numbers of individuals across many states and into Canada. While most individuals can recover from a foodborne illness without any need for medical attention, some patients such as the very young, the very old, and those who may be otherwise immuno-compromised may suffer complications and even death.

This publication provides a brief outline of the fundamental components of microbial food safety that should be part of any comprehensive management plan for growers, specialty crop producers, harvest service operators, distribution and wholesale handlers, direct marketers, and fresh cut processors. The diversity of environments, crop management practices, and handling practices makes the notion a single, universally applicable approach to food safety planning unrealistic. Instead, this quick reference guide focuses on the key guiding principles: prevention of contamination, reduction of survival, and prevention of cross-contamination for each step, up to consumer handling. You can create your own food safety planning and management programs based on the application of these principles, which are the combined results of specific research and practical experience with diverse commodities and crop management systems.

Many of these same principles can be applied to planning for food security and the prevention of intentional food contamination. Helpful resources related to counter-bioterrorism planning are provided at the end of this publication.

\section{WHAT ARE THE GUIDING PRINCIPLES OF FOOD SAFETY FOR FRESH PRODUCE?}

- Once produce has been contaminated, removing or killing the pathogens is very difficult.

- Prevention of microbial contamination at all steps from production to distribution is strongly favored over treatments to eliminate contamination after it has occurred.

- Documentation of the implementation of prevention programs and food safety awareness training for workers at all levels of the agricultural and packing environments are key elements in a credible food safety program.

\section{GUIDING PRINCIPLES FOR CROP PRODUCTION WATER}

Wherever water comes into contact with fresh produce, its quality may directly determine the potential for persistent pathogen contamination.

- Become familiar with the routes and handling of surface water sources, seasonal influences on water quality, and any microbial monitoring programs followed by the supplier (for delivered water from public or private irrigation districts).

- Identify potential sources of contamination that could affect your water, especially those that are within your ability to control in a manner that would protect water quality.

- Ensure that wells are designed and maintained in a manner that prevents surface run-off and soil infiltration from contaminating the water supply.

- Water used for any foliar application should come from a pathogen-free source.

- Until more research data are available, we strongly recommend that any foliar applications within two weeks of harvest be from a potable water source. 


\section{GUIDING PRINCIPLES FOR MANURE AND MUNICIPAL BIOSOLIDS}

Properly composted manures or municipal biosolids are not a source of microbial pathogens on fresh produce.

- Become informed about proper compost management for pathogen reduction, and document the methods used to eliminate pathogens from any manure that you apply.

- Document or obtain documentation about the specific compost management practices used for each lot.

- Maximize the time between the date you apply manure to production areas and the date you harvest those areas.

- If you practice multi-season drip irrigation, the spreading of manure without incorporating it into the soil requires careful attention to ensure that pathogen reduction practices have been followed and documented.

\section{GUIDING PRINCIPLES FOR MINIMIZING ANIMAL FECAL CONTAMINATION}

It is not possible, or may not be permissible, to eliminate all animal influences from production fields. All the same, you need to determine what steps you can take to minimize their presence or activities.

- Domestic animals should be excluded from fields during the growing and harvesting season.

- Evaluate the need for bare soil buffers between your produce fields and adjacent land. Buffers can discourage the movement of reptiles, amphibians, and rodents-all potential sources of contamination-into your fields.

- Minimize the presence of vector attractants (such as cull piles) within a production field.

\section{GUIDING PRINCIPLES FOR WORKER HEALTH AND HYGIENE}

There is no substitute for awareness, training, and constant reinforcement regarding the importance of each worker's personal hygiene and sanitation as critical elements in maintaining a sustainable business for you and continued employment for the worker.

- Follow all OSHA and CAL OSHA requirements for sanitary facilities.

- Establish a training program that includes proper hand washing techniques and the importance of using toilet facilities.

- Establish and communicate a clear policy that will allow workers who report or are observed to have symptoms of illness or diarrhea to be reassigned to paid activities that do not involve food or food surface contact. In the absence of such a policy, it is likely that workers will not report their illnesses for fear that they will lose wages.

- Carefully inspect areas that are frequented by unsupervised workers (such as night irrigators) for signs that additional training is needed.

- Provide bandages or other protective coverings to workers who have cuts or lesions that may make contact with fresh produce.

- If the workers use gloves, provide instruction on their proper use to prevent the transfer of pathogens to fresh produce.

- Use caution when servicing portable toilets to prevent leakage into a field.

- Provide physical diversion and containment in the event of waste spillage. Have a plan for how to isolate and destroy contaminated produce in the event of a spill. 


\section{GUIDING PRINCIPLES FOR FIELD AND HARVEST SANITATION}

All surfaces and implements that touch fresh produce must be treated as food contact surfaces.

- Clean all food contact surfaces and harvest containers or bins prior to use.

- Ensure that harvest contractors and crews are aware of the principles of microbial food safety risk reduction and that they adhere to established food safety practices.

- Develop and document a system of cleaning and sanitizing food contact surfaces.

- Minimize the opportunity for disease vectors (rats, mice, flies, reptiles, and amphibians) to contaminate packing surfaces and materials.

- Minimize vectors' access or attraction to harvest equipment kept in the field (for instance, do not leave damaged produce or heavy juice residues on belts or grading tables).

\section{GUIDING PRINCIPLES FOR PACKING FACILITIES}

Well-designed and operated centralized packing facilities and packing systems have the potential to contribute to the reduction of pathogen contamination. Management lapses in facilities or systems have the potential to amplify any localized contamination, broadly redistribute pathogens, or create opportunities for pathogen contamination within the facility.

- Design and maintain packing surfaces and equipment to minimize injury to the produce and to maximize accessibility for cleaning or sanitizing.

- Establish routine cleaning and sanitizing programs for all food contact surfaces.

- Remove as much dirt as is practical from harvest containers, trailers, or gondolas between harvest uses. This should be done outside of the packing facility, away from any water source that is used for postharvest handling.

- Clean pallets, containers, or bins before use.

- Establish and maintain a pest control program.

- Prevent birds and other vectors from contaminating packing equipment surfaces, packing areas, and storage areas.

- Store unformed or empty containers off the floor or bare soil surface and in a way that protects them from contamination.

\section{GUIDING PRINCIPLES FOR POSTHARVEST WATER DURING PACKING}

The quality of the water that contacts fresh produce during postharvest cleaning, grading, cooling, and surface treatment application is widely recognized as the essential pathogen control point for fresh produce.

- Follow programs typical of Good Manufacturing Practices (GMP) to ensure that all water is of adequate quality throughout all packing operations from start-up to the last packed unit.

- Antimicrobial chemicals help minimize the potential for microbial contamination to spread in packing operation water; levels of antimicrobial chemicals must be routinely monitored and recorded to ensure they stay at appropriate levels.

- Special attention to water quality is required for dump tank systems and recirculated water. 
- Keep air-cooling and chilling equipment clean and sanitary.

- Transport, store, and use ice under sanitary conditions.

\section{GUIDING PRINCIPLES FOR TRANSPORTATION}

Limited control is possible beyond the shipping dock, but the consequences of crosscontamination during transportation and distribution will be linked back to the handler and grower.

- Inspect transportation vehicles for cleanliness, odors, and obvious dirt and debris before loading. If necessary, insist that trailers or containers be cleaned out before loading.

- Ensure that transporters, distributors, and retailers maintain the integrity of the positive lot identification and traceback systems you are using.

\section{GUIDING PRINCIPLES FOR STORAGE AND DISTRIBUTION}

Well-designed and operated wholesale distribution, load consolidation, and crossdocking facilities have the potential to maintain the integrity of a pathogen-free product. Lapses in facility sanitation or system management have the potential to amplify localized contamination, promote the internalization of pathogens into products, and broadly redistribute pathogens.

Mixed storage and mixed load distribution have the potential to transfer contamination from one lot or product to a previously uncontaminated produce item, especially where pallet-stacking, ice injection, or top-icing is involved.

- Be aware of the potential for cross-contamination.

- Separate dry and wet products and place water-repellant shipping barriers between commodities in mixed loads.

\section{GUIDING PRINCIPLES FOR FRESH CUT OR VALUE-ADDED PROCESSING}

Well-designed and operated processing facilities have the potential to contribute to the reduction of pathogen contamination. Lapses in facility or system management have the potential to amplify localized contamination, broadly redistribute pathogens within or among lots, or contaminate pathogen-free produce from within the facility during handling.

Washing, in combination with a disinfectant treatment, will reduce but will not eliminate microbial contamination. Greater microbial reductions are achieved on smooth, waxy produce than on rough-textured or porous produce.

For produce that can tolerate more vigorous handling, mechanical cleaning in the form of brush-washing in combination with treatment with an approved antimicrobial agent can increase the efficiency of cleaning before cutting or dicing.

Proper temperature management (cold chain control) is important for quality and safety management, but you cannot rely upon it alone to provide sufficient consumer protection from the potential of foodborne illness.

- Carefully evaluate the need to remove produce with open wounds (other than the typical wounds created at the moment of harvest) or defects that may have allowed bacteria to become internalized. Avoid produce with visible sunken areas and eliminate produce with areas of mold or decay. 
- Product flow should be linear; incoming product should not cross paths or be stored next to cleaned or processed product. Ideally, packing areas should be physically separated from receiving and processing areas.

- Worker traffic flow and activities should not move between packing and receiving.

- Develop specific worker training programs for fruit handling and processing to prevent bare-hand or gloved-hand contact with uncleaned fruit rind and cut fruit flesh, in sequence, by the same individual.

- Antimicrobial chemicals help minimize the potential for microbial contamination to be spread by process water. Levels of antimicrobial chemicals must be routinely monitored and recorded to ensure that they are maintained at appropriate levels.

- Special attention to water quality is required for common wash tank or flume systems and any recirculated water.

\section{GETTING STARTED: RESOURCES TO UNDERSTAND AND MINIMIZE MICROBIAL RISKS TO FRESH PRODUCE}

\section{Production and Postharvest}

On-Farm Food Safety Self Audit and Resource CD-ROM

http://vric.ucdavis.edu

http://ucgaps.ucdavis.edu

Food Safety Begins on-the-Farm Brochure (English and Spanish)

http://www.gaps.cornell.edu

Overview of Good Agricultural Practices

Final Guidance: Guide to Minimize Microbial Food Safety Hazards for Fresh Fruits and Vegetables (FDA 1998)

http://www.foodsafety.gov/ dms/prodguid.html

\section{Systemwide Biosecurity}

Food Security and Bioterrorism Checklist: Food Safety and Terrorism

http://www.cfsan.fda.gov/ dms/fsterr.html

Food Security Guidance, Federal Register N otice of Availability (2002)

http://www.cfsan.fda.gov/ /rd/fr020109.html

Guidance for Industry: Food Producers, Processors, Transporters and Retailers: Food Security Preventive Measures Guidance

http://www.cfsan.fda.gov/ dms/secguid.html

Guidance for Industry: Importers and Filers: Food Security Preventive Measures

Guidance

http://www.cfsan.fda.gov/ dms/secguid2.html 


\section{FOR MORE INFORMATION}

You'll find detailed information on many aspects of food safety and postharvest handling in these titles and in other publications, slide sets, CD-ROMs, and videos from UC ANR:

Don't Give Kids a Tummyache!, publication 21586

Ready of N ot? Planning for and Emergency, publication ANRP014

Postharvest Technology of Horticultural Crops, publication 3311

To order these products, visit our online catalog at http://anrcatalog.ucdavis.edu. You can also place orders by mail, phone, or FAX, or request a printed catal og of publications, slide sets, CD-ROMs, and videos from

University of California

Agriculture and Natural Resources

Communication Services

6701 San Pablo Avenue, 2nd Floor

Oakland, California 94608-1239

Telephone: (800) 994-8849 or (510) 642-2431, FAX: (510) 643-5470

e-mail inquiries: danrcs@ucdavis.edu

An electronic version of this publication is available on the ANR Communication Services Web site at http://anrcatalog.ucdavis.edu.

\section{Publication 8102}

(c) 2003 by the Regents of the University of California, Division of Agriculture and Natural Resources. All rights reserved.

The University of $\mathrm{C}$ alifornia prohibits discrimination against or harassment of any person employed by or seeking employment with the University on the basis of race, color, national origin, religion, sex, physical or mental disability, medical condition (cancer-related or genetic characteristics), ancestry, marital status, age, sexual orientation, citizenship, or status as a covered veteran (special disabled veteran, Vietnam-era veteran or any other veteran who served on active duty during a war or in a campaign or expedition for which a campaign badge has been authorized).

University Policy is intended to be consistent with the provisions of applicable State and Federal laws.

Inquiries regarding the University's nondiscrimination policies may be directed to the Affirmative Action/Staff Personnel Services Director, University of California, Agriculture and N atural Resources, 300 Lakeside Drive, 6th Floor, Oakland, CA 94612-3550 (510) 987-0096. For information about obtaining this publication, call (800) 994-8849. For downloading information, call (530) 754-5112.

pr-5/03-WJC/VFG

ISBN 978-1-60107-276-4

Partial support for the production and distribution of this brochure is contributed by the $\mathrm{N}$ ational Good Agricultural Practices Training Program

(USDA CSREES Agreement \# 99-41560-0821)

This publication has been anonymously peer reviewed for technical accuracy by University of California scientists and other qualified professionals. The review process was managed by the ANR Associate Editor for Food and Nutrition. 